УДК 373.2:613/614:004:001.895(045)

DOI: 10.31339/2617-0833-2019-2(27)-111-115

ОСОБЛИВОСТІ ВИКОРИСТАННЯ ЗДОРОВ'ЯЗБЕРІГАЮЧИХ ТЕХНОЛОГІЙ В ДОШКІЛЬНІЙ ОСВІТІ

Микуліна А. К., Любежаніна Б. А.

\title{
THE PECULIARITIES OF USING HEALTH SAVING TECHNOLOGIES IN PRESCHOOL EDUCATION
}

Mykulina Antonina, Lubazhanina Bogdana

У статті розкривається проблема здоров'яспрямованої діяльності в дошкільній освіті та як засіб ї̈ вирішення - здоров'язберігаючі технології. Охарактеризовані основні поняття, розкрито мету, види, принциипи та умови реалізації здоров'язберігаючих освітніх технологій в навчально-виховному прочесі сучасного дошкільного закладу, які впливають на формування ефективного здоров'язберігаючого середовища в умовах дошкільної освіти. Також визначено роль батьків у встановленні доброзичливих та відкритих відносин між дітьми, батьками та педагогами в реалізації даної проблеми.

Ключеві слова: здоров'язберігаючі технології, компетентність, педагогічний процес, здоров'язбереження, фізкультурно-оздоровча робота, валеологічна культура.

The article has revealed the problem of health-oriented activities in preschool education and as means of solving it - health-saving technologies. There have been described basic conceptions, purpose, types, principles and conditions of realization of health-saving educational technologies in educational process of modern preschool institution.

Health-saving educational technologies in a preschool educational establishment are firstly technologies for the upbringing of valeological or pre-school health culture. The purpose of these technologies is to become aware of the child's attitude to his or her health and human life, to acquire valeological competence.

Providing valeological education to parents of preschoolers has been a goal of technology, in the implementation of which they are actively acquainted with the main issues of preserving and promoting the health of children and master the practice of forming a healthy space in family centers.

The implementation of a holistic system for the formation of health-saving competence of all participants in the educational process takes place under certain conditions, and its result is the formation of an effective health-saving environment in pre-school education.

Key words: health saving technologies, competence, pedagogical process, health saving, physical and health work, valeological culture.

Проблеми фізичного розвитку дошкільнят, зміцнення та збереження їхнього здоров'я ніколи не втрачають своєї актуальності. Тому найактуальнішою проблемою на сьогоднішній день є зміцнення здоров'я дітей. Кожна дитина має бути здоровою і щасливою, від цього залежить комфортність іï життя. Якщо дитина має міцне здоров'я, повноцінний фізичний розвиток, багатий руховий досвід, це слугує твердим підгрунтям їі подальшого розвитку, основою оволодіння загальнолюдськими цінностями, формування iĭ розумового, творчого потенціалу та власного особистісного становлення.

Фізичне здоров'я є одним із важливих компонентів у складній структурі стану здоров'я дитини та зумовлює життєздатність організму.

Зусилля працівників дошкільної освіти сьогодні як ніколи спрямовані на оздоровлення дитини-дошкільника, культивування здорового способу життя. Невипадково, саме ці завдання є пріоритетними у сучасній освіті. 
Одним із засобів вирішення означеної проблеми стають здоров'язберігаючі технології, без яких немислимий педагогічний процес сучасного дошкільного закладу. Але що таке здоров'язберігаючі технології в педагогічному процесі ЗДО і що ними вважають - до цих пір залишається неузгодженим для широкого кола професійно-педагогічної аудиторії і навіть для тих, хто впевнено використовує ці технології у своїй практиці.

Однією з провідних проблем здоров'яспрямованої діяльності в дошкільних закладах є визначення критеріїв діяльності педагогічного і дитячого колективів. Показники якості та дієвості здоров'яспрямованої діяльності в освітніх закладах розглядали науковці В. Оржеховська, О. Кононко, С. Кириленко, С. Омельченко, Т. Андрущенко, інші відзначили передусім ціннісне ставлення до здоров'я, рівень сформованості у дітей фізичних навичок, витривалості. Проблему загартування дітей досліджували такі вчені як: Е. Вільчковський, Д. Хухлаєва, А. Кенеман й ін. Фізичне виховання як один з елементів суспільного виховання розглядали П. Лесгафт, Е. Аркін, І. Муравйов, А. Ляхович, М.Сфименко, А. Бикова та інші [3].

Мета статті: теоретично обгрунтувати завдання, мету, види та принципи реалізації здоров'язберігаючих освітніх технологій в дошкільній освіті.

«Здоров'язберігаюча технологія» - це система заходів, що включає взаємозв'язок і взаємодію всіх факторів освітнього середовища, спрямованих на збереження здоров'я дитини на всіх етапах ії навчання і розвитку. У концепції дошкільної освіти передбачено не тільки збереження, а й активне формування здорового способу життя і здоров'я вихованців [4,с.13].

Здоров'язберігаючий педагогічний процес в ЗДО - в широкому сенсі слова - процес виховання i навчання дітей дошкільного віку в режимі здоров'язбереження; процес, спрямований на забезпечення фізичного, психічного і соціального благополуччя дитини [2, c.114].

Здоров'язбереження і здоров'язбережувальна компетентність - найважливіші умови ефективної організації педагогічного процесу в ЗДО. Найважливішою характеристикою педагогічної технології є іiі доцільність. Будь яка сучасна педагогічна технологія повинна бути здоров'язберігаючою.

Здоров'язберігаючі технології в дошкільній освіті перш за все спрямовані на вирішення пріоритетного завдання сучасної дошкільної освіти - завдання збереження, підтримки і збагачення здоров'я суб'єктів педагогічного процесу в дитячому садку: дітей, педагогів та батьків [4, с.14].

Мета здоров'язберігаючих технологій в дошкільній освіті стосовно до дитини забезпечення високого рівня реального здоров'я вихованця дошкільного закладу і виховання валеологічної культури як сукупності усвідомленого ставлення дитини до здоров'я і життя людини, знань про здоров'я і умінь оберігати, підтримувати і охороняти його, валеологічної компетентності, що дозволяє дошкільнику самостійно і ефективно вирішувати завдання здорового способу життя і безпечної поведінки, завдання, пов'язані з наданням елементарної медичної, психологічної самодопомоги та допомоги. Стосовно до дорослих - сприяння становленню культури здоров'я, в тому числі культури професійного здоров'я вихователів ДНЗ і валеологічної освіти батьків [2, с.115].

Види здоров'язберігаючих технологій в дошкільній освіті це класифікація здоров'язберігаючих технологій по домінуванню цілей i розв'язуваних задач, а також провідних засобів здоров'язбереження i здоров'язбережувальних компетенцій суб'єктів педагогічного процесу в ЗДО. У зв'язку 3 цим можна виділити наступні види здоров'язберігаючих технологій у дошкільній освіті:

- медико-профілактичні;

- фізкультурно-оздоровчі;

- технології забезпечення соціально-психологічного благополуччя дитини;

- здоров'язбережувальні технології і компетентності серед педагогічних працівників дошкільної освіти; 
- валеологічна освіта батьків [4,с.16].

Медико-профілактичні технології в дошкільній освіті - технології, що забезпечують збереження і примноження здоров'я дітей під керівництвом медичного персоналу ЗДО відповідно до медичних вимог і норм, з використанням медичних засобів. До них належать такі технології: організація моніторингу здоров'я дошкільнят та розробка рекомендацій по оптимізації дитячого здоров'я, організація і контроль харчування дітей раннього та дошкільного віку, фізичного розвитку дошкільників, загартовування; організація профілактичних заходів у дитячому садку; організація здоров'язберігаючого середовища в дошкільній установі [1,с.39].

Фізкультурно-оздоровчі технології у дошкільній освіті - технології, спрямовані на фізичний розвиток і зміцнення здоров'я дитини: розвиток фізичних якостей; раціональної рухової активності і становлення фізичної культури дошкільнят; ранкова гімнастика, фізкультурні заняття, гімнастика пробудження після денного сну, фізкультхвилинки і паузи; загартовування, зорова, дихальна гімнастика, масаж i самомасаж, профілактика плоскостопості і формування правильної постави, оздоровчі процедури в водному середовищі (басейні) і на тренажерах; спортивне дозвілля та розваги, свята. Все це сприяє вихованню звички до повсякденної фізичної активності і турботі про здоров'я. Реалізація цих технологій, як правило, здійснюється фахівцями з фізичного виховання та вихователями ЗДО в умовах спеціально організованих форм оздоровчої роботи та в повсякденні. Окремі прийоми цих технологій широко використовуються педагогами дошкільної освіти в різних формах організації педагогічного процесу: на заняттях і прогулянках, в режимних моментах, у вільній діяльності дітей, в ході педагогічної взаємодії дорослого з дитиною [3].

В якості основних принципів ефективної реалізації здоров'язберігаючих освітніх технологій можна виділити:

1. Створення освітнього середовища, що забезпечує зняття всіх стресових факторів навчально-виховного процесу. Атмосфера доброзичливості, віра в сили дитини, індивідуальний підхід, створення для кожного ситуації успіху необхідні не тільки для пізнавального розвитку дітей, а й для їх нормального психофізіологічного стану.

2. Творчий характер освітнього процесу. Навчання без творчого заряду нецікаво, а значить $є$ насильством над собою та іншими. Можливість для реалізації творчих завдань досягається використанням на заняттях, і в повсякденній роботі активних методів і форм навчання.

3. Забезпечення мотивації освітньої діяльності. Дитина - суб'єкт виховання i навчального спілкування, вона повинна бути емоційно залученою в процес успішної соціалізації, що забезпечує природне підвищення працездатності та ефективності роботи мозку не на шкоду здоров'ю.

4. Побудова освітньо-виховного процесу відповідно до закономірностей становлення психічних функцій. Перехід від спільних дій до самостійних, від дії наслідування до появи плану виконання дії, перехід від розгорнутих поетапних дій до згорнутих і автоматизованих.

5. Врахування особливостей вищих психічних функцій.

6. Усвідомлення дитиною успішності в будь-яких видах діяльності.

7. Раціональна організація рухової активності. Поєднання методик оздоровлення та виховання дозволяє домогтися швидкої та стійкої адаптації дитини до умов дитячого садка: до $50 \%$ знижуються загальна захворюваність, загострення хронічних захворювань, пропуски через хворобу.

8. Забезпечення адекватного відновлення сил. Зміна видів діяльності, регулярне чергування періодів напруженої активної роботи і розслаблення, зміна довільної та емоційної активації необхідна щоб уникнути перевтоми у дітей.

9. Забезпечення міцного запам'ятовування. Науково обгрунтована система повторення та закріплення - необхідна умова здоров'язберігаючих технологій [3, с.47].

Вихователь також може ефективно займатись формуванням здоров'язбережувальних 
компетентностей серед вихованців та їх батьків, так як в цій роботі необхідний перш за все особистий приклад.

Забезпечення валеологічної освіченості батьків вихованців ДНЗ є метою технології, що використовується в системі роботи з батьками. При реалізації даної технологіі батьки активно знайомляться з основними питаннями збереження і укріплення здоров'я дітей та оволодівають практикою формування здоров'язберігаючого простору в сімейних осередках $[2$, c.59].

Основна мета всіх форм і видів взаємодії в рамках організації здоров’язберігаючого середовища 3 родиною - встановлення доброзичливих та відкритих відносин між дітьми, батьками та педагогами, об'єднання їх в одну команду, виховання потреби ділитися один 3 одним своїми проблемами і спільно їх вирішувати.

Взаємодія педагогів і батьків дітей дошкільного віку здійснюється в основному через:

- залучення батьків до педагогічного процесу;

- розширення сфери участі батьків у організації життя освітнього закладу;

- перебування батьків на заняттях у зручний для них час;

- створення умов для творчої самореалізації педагогів, батьків, дітей;

- інформаційно-педагогічні матеріали, виставки дитячих робіт, які дозволяють батькам ближче познайомитися зі специфікою роботи та результатами установи по створенню здоров'язберігаючого розвивального середовища;

- різноманітні культурно-освітні та психолого-педагогічні програми спільної діяльності дітей і батьків [1, с,83].

Об'єднання зусиль педагога і батьків у спільній діяльності з виховання та розвитку дитини: ці взаємини слід розглядати як мистецтво діалогу дорослих з конкретною дитиною на основі знання психічних особливостей ії віку, враховуючи інтереси, здібності і попередній досвід дитини, прояв розуміння, толерантності і такту у вихованні та навчанні, прагнення враховувати ii інтереси, не ігноруючи почуття та емоції. Отже, відносини дошкільного закладу з сім'єю повинні бути засновані на співпраці і взаємодії за умови відкритості дошкільного закладу.

Отже, основними умовами ефективності моделі фізкультурно-оздоровчої роботи 3 дітьми в закладах дошкільної освіти є :

- опанування педагогом здоров'язбережувальними технологіями, методикою фізичного виховання та розвитку дошкільників в сучасному ЗДО;

- створення відповідного середовища для збереження здоров'я дітей, активне використання нетрадиційного фізкультурно-оздоровчого обладнання;

- $\quad$ єдність підходів обох вихователів і батьків до запроваджуваної технології;

- індивідуальний підхід при застосуванні засобів для зміцнення імунітету та під час психопрофілактичної роботи;

- дотримання належного температурного режиму в групах та в ЗДО;

- постійний медико-педагогічний контроль за станом здоров'я дітей.

Саме за таких умов можлива реалізація цілісної системи по формуванню здоров'язбережувальної компетентності усіх учасників освітньо-виховного процесу і як результат - формування ефективного здоров'язберігаючого середовища в умовах дошкільної освіти.

Отже, здоров'язберігаючі освітні технології в дошкільному закладі - це насамперед технології виховання валеологічної культури чи культури здоров'я дошкільнят, метою яких $\epsilon$ формування усвідомленого ставлення дитини до здоров'я, набуття валеологічної компетентності та розвиток вміння оберігати, підтримувати і зберігати своє здоров'я протягом усього життя. 


\section{Список використаних джерел}

1. Вільчковський Е.С. Організація рухового режиму дітей 5-10 років у закладах освіти / Е.С. Вільчковський, Н.Ф. Денисенко. - Запоріжжя, 2006. - 228c.

2. Волошина Л. Організація здоров'язберігаючого простору / Л. Волошина // Дошкільне виховання. - 2004. - №1. - С.114-117.

3. Оздоровча робота в дошкільному навчальному закладі : навч. посіб. / Г.І. Григоренко, Н.Ф. Денисенко, Ю.О. Коваленко, Н.В. Маковецька. - Запоріжжя : ЗНУ, 2006. - 99 с.

4. Рубан Н. Здоров'ятворчі та здоров'язбережувальні технології / Н. Рубан // Палітра педагога. - 2010. - № 2. - С. 12-17.

\section{References}

1.Vil'chkovs'kyy, E.S. and Denysenko, N.F. 2006. Orhanizatsiya rukhovoho rezhymu ditey 5-10 rokiv $u$ zakladakh osvity [Organization of movement regime of children 5-10 years in educational establishments]. Zaporizhzhia.

2. Voloshyna, L. 2004. Orhanizatsiya zdorov'yazberihayuchoho prostoru [Organization of health care space]. Preschool education, 1, pp. 114-117.

3. Hryhorenko, H.I., Denysenko, N.F., Kovalenko, Yu.O. and Makovets'ka, N.V. 2006. Ozdorovcha robota $v$ doshkil'nomu navchal'nomu zakladi [Wellness work in a preschool institution]. Zaporizhia: ZNU.

4. Ruban, N. 2010. Zdorov'yatvorchi ta zdorov'yazberezhuval'ni tekhnolohiyi [Health creation and health care technologies]. Teacher palette, 2, pp. 12-17.

УДК 37.091.2:316.72:821(045)=111

DOI: 10.31339/2617-0833-2019-2(27)-115-119

\section{WORLD LITERATURE AS A MULTICULTURAL COMPONENT OF THE EDUCATIONAL PROCESS}

Myslo Diana, Rozman Iryna

\section{СВІТОВА ЛІТЕРАТУРА ЯК МНОГОКУЛЬТУРНИЙ КОМПОНЕНТ НАВЧАЛЬНОГО ПРОЦЕСУ}

Мисло Д., Розман I.I.

The article deals with the importance of the component of foreign literature as a source of spiritual and social progress of the young generation of Ukrainians. It is emphasized that young people, while living in a globalized world, must adequately respond to the problems and challenges of today. It is stated that foreign literature teaches to formulate their thoughts correctly, to be able to perceive the beauty of the surrounding world, to contribute to a better understanding of other people, their experiences, aspirations, feelings and hopes. Emphasis is placed on the determination that multiculturalism is one of the tendencies of the world educational reform process. Separately, the reform of the educational process in Ukraine is aimed at cultural-centricity, which foresees new approaches to the preparation of student youth at universities for life in modern society. The article substantiates that multicultural education should be carried out on the basis of the following approaches: personality-oriented, cultural, comparative and systematic.

Key words: polyculture, development of thinking, foreign literature, educational process.

У статті розглядаються питання про важливість складової зарубіжної літератури як джерело духовного й сочіального поступу молодого покоління украӥнців. Наголочено на тому, ще молоді люди, живучи в глобалізованому світі повинні адекватно реагувати на проблеми й виклики сучасності. Зазначено, що зарубіжна література навчає правильно 